The Holocece (Forum Paper) - accepted 30 December 2015

\title{
The neotropical Gran Sabana region: palaeoecology and
}

\section{conservation}

Valentí Rull, ${ }^{1}$ Teresa Vegas-Vilarrúbia ${ }^{2}$ and Encarni Montoya ${ }^{1}$

${ }^{1}$ Institute of Earth Sciences Jaume Almera (ICTJA-CSIC), Barcelona, Spain

${ }^{2}$ Department of Ecology, Universitat de Barcelona, Barcelona, Spain

Corresponding author:

Valentí Rull, Department of Environmental Geology and Geohazards, Institute of Earth Sciences Jaume Almera (ICTJA-CSIC), C. Solé I Sabarís s/n, 08028 Barcelona, Spain. Email: vrull@ictja.csic.es 


\section{Abstract}

The Gran Sabana (GS) is a key region for understanding the origin of neotropical savannas and is an ideal location to test ecological hypotheses on long-term vegetation dynamics under the action of natural and anthropogenic drivers. The conservation of the GS is a controversial issue because of the confluence of disparate cultural and socio-economic interests, with a strong debate surrounding fire practices by indigenous people. Late glacial to Holocene pollen and charcoal records obtained thus far in this region have documented the main palaeoecological trends along with the climatic and anthropogenic (mostly fire) drivers involved. Here we discuss how these records can be used to inform conservation and restoration practices in the GS. The main points of the discussion are the local vs. regional character of palaeoecological evidence, the support provided by this evidence for the existing fire management proposals and the role of spatiotemporal environmental and ecological heterogeneity in the definition and evaluation of realistic restoration targets. A general conclusion is that past ecological reconstructions do not fully support either of the current options for fire management, i.e., either total fire suppression or the continuity of indigenous fire practices. It is recommended to replace this dual and rigid conservation framework with a more diverse and flexible approach that considers the complex spatiotemporal heterogeneity documented in palaeoecological records.

Keywords: Palynology, Holocene, Late glacial, fire, conservation, savanna, Neotropics 


\section{Introduction}

The Gran Sabana (GS) is the Venezuelan part of the Roraima savannas, shared with Brazil and Guyana, which constitute a huge savanna patch $\left(\sim 70,000 \mathrm{~km}^{2}\right)$ situated within the extensive Orinoco-Amazon rainforests (Fig. 1). The GS has been considered a key region for the study of the origin of neotropical savannas and the natural and anthropogenic drivers involved, as well as a key region to test ecological and biogeographical hypotheses and models using long-term palaeoecological records (Rull et al, 2013, 2015). Regarding conservation, the GS is a problematic region, as it is simultaneously the home of the Pemon indigenous culture, part of the Canaima National Park, and the headwaters of the Caroní River, which is intensively exploited for hydroelectrical power (Castro and Gorzula, 1986). Combining the interests of all these actors and stakeholders to develop feasible conservation strategies is a timely topic, which is under active discussion in many parts of the world (e.g., Schmidt and Peterson, 2009; Middleton, 2013; Welch, 2014; Fache and Moizo, 2015). In the GS, the debate has focused on the indigenous use of fire as a deforestation agent favouring the expansion of savannas. Owing to its cultural, socio-political and economic implications, this debate exceeds the ambit of ecology and demands an urgent solution. The potential role of palaeoecology in informing conservation practices in the GS, especially in relation to fire management, was highlighted recently (Montoya and Rull, 2011; Vegas-Vilarrúbia et al., 2011) and has been retaken recently in this journal (Leal et al., in press). Palaecological results obtained in the last years (Rull et al., 2013, 2015; Leal et al., in press) enable more specific assessments with potential practical repercussions. The main recent developments in this regard have been: i) the attainment of a more detailed regional picture of past ecological trends, ii) the identification of the timing and potential causes of the initial GS savannization, iii) a more precise record of the ecological states of the GS during the Holocene, and iv) the recognition of the high spatiotemporal ecological heterogeneity of the GS. In this forum paper, we discuss these advancements and 
their potential contribution to conservation and restoration practices in the GS region. Our aim is not to propose specific conservation actions, which would be more appropriate for a conservation journal, but to highlight the palaeoecological information that we consider useful for guiding conservation stategies. Cultural, ideological and socio-political matters are also relevant to the debate but are beyond the scope of this paper.

\section{Regional palaeoecological trends}

The GS uplands (ca. 800 to $1300 \mathrm{~m}$ elevation) are mostly covered by treeless savannas dominated by grasses, with savanna-forest mosaics at the ecotones with the surrounding forests (Huber, 1995a). Montane forests are highly diverse and their composition varies with elevation (Hernández et al., 2012). Gallery forests are also common along rivers and on lake shores. A special vegetation is the so called "morichal", a monospecific palm swamp of Mauritia flexuosa growing on flooded areas such as lake shores and riverbanks (Fig. 1). The GS has two well differentiated physiographical regions separated by a more or less abrupt ramp of $400 \mathrm{~m}$ : the northern sector, with average elevations between $1200-1300 \mathrm{~m}$, and the southern sector, mostly between 800 and 900 m in elevation (Huber \& Febres, 2000). This topographical configuration determines the occurrence of contrasting bioclimatic conditions with a conspicuous landscape expression. The climate of the northern sector is slightly cooler and wetter and is characterized mainly by savannas, broad-leaved meadows and shrub lands, with frequent montane and gallery forests. Morichales are absent. In the southern sector, where climates are warmer, drier and more seasonal, the open savannas dominate the landscape, the shrub lands are less frequent and the broad-leaved meadows are absent. The morichales are characteristic of this sector, where they develop dense and extensive stands. 
Palaeoecological records published to date using pollen and charcoal analysis to reconstruct vegetation dynamics in relation to fire and climate changes have been restricted mostly to the southern GS sector. The main results of these previous studies, in terms of millennial-scale vegetation and landscape changes, are summarized in Rull et al. $(2013,2015)$ (Fig. 2). During the last 13,000 years, two main phases of fire exacerbation are recorded: the first during the Younger Dryas (YD) and the Early Holocene (EH) and the second during the last 2000 years. The rest of the Holocene was characterized by lower but sustained fire incidence. The YD-EH fires were likely responsible for a hitherto-irreversible savannization process, which occurred between 13,000 and $10,000 \mathrm{cal}$ BP, depending on the site. The southern GS landscape was dominated by treeless savannas during the whole Holocene, with a more or less general expansion of gallery forests around lakes and rivers between ca. 7000 and 5000 cal BP. A more significant vegetation change occurred in the last 2000 years, with the general expansion of treeless savannas and morichales (which were absent in the GS before that time) at the expense of montane and gallery forests, respectively, and a process that is still ongoing. This coincided with the second phase of fire intensification, with burning patterns and ecological consequences similar to those observed presently, which suggests that the indigenous culture currently living in the GS arrived and expanded since $2000 \mathrm{cal}$ BP.

Leal et al. (in press) published the first detailed palynological record of the northern GS, which documents the vegetation changes that occurred during the last $\sim 3000$ years. The more relevant ecological change was observed at 1600-1800 cal BP and consisted of the replacement of gallery forests by open savannas under the action of anthropogenic fires, favoured by climatic conditions. Such a vegetation shift is consistent with the results obtained so far in the southern sector where the replacement of forests by open savannas and morichales started by 2000 cal BP and likely progressed from south to north, reaching the northern GS sector slightly later (Rull and Montoya, 2014). The results of Leal et al. (in press) 
for the human-driven disappearance of northern gallery forests by $1600-1800$ cal BP support the hypothesis of the northward expansion of human populations across the whole GS, thus providing a more geographically-extensive ecological and cultural picture. However, some differences exist in the vegetation types involved. Indeed, the Late Holocene gallery forests of the northern and southern sectors have different taxonomical composition, as it occurs currently (Huber and Febres, 2000). In addition, the expansion of morichales occurred only in the southern sector, owing to the inability of Mauritia to colonize the northern sector due to climatic constraints. Specifically, this palm needs warm and wet climates and flooded soils to develop successfully and such environments occur in the GS only in the southern sector and below 1000 m elevation (Rull and Montoya, 2014).

\section{Palaeoecology and fire management}

The issue of management for conservation in the GS is problematic because of the confluence of several disparate cultural, socio-political and economic interests. On the one hand, the state hydroelectric company CORPOELEC (formerly EDELCA) and a number of ecologists and conservationists are committed to preserving GS forests to protect the headwaters of the Caroní River. Most of these actors believe that the GS was formerly covered by forests that were later removed by human fires and blame the present GS indigenous people and their ancestors for this presumably-recent historical deforestation. The defenders of this proposal advocate for the immediate cessation of indigenous fires. Since 1980, EDELCA has actively combated these fires by means of helicopter-supported fire brigades with the active participation of indigenous people as firemen (Huber, 1995b). On the other hand, the defenders of the indigenous practices argue that fire is a fundamental cultural trait that should be preserved not only for cultural reasons but also because of its potential usefulness in conservation. Indeed, these actors contend that current fire management practices by 
indigenous people hampers the accumulation of natural fuels, thus preventing the occurrence of larger and potentially catastrophic fires (Bilbao et al., 2010; Leal et al., in press). In contrast with other neotropical savanna regions, as for example the Brazilian "cerrados" (Da Silva and Bates, 2002; Klink \& Machado, 2005), GS fires are not lit to facilitate agriculture or other economic activities but for disparate reasons including plague control, hunting, savanna cleaning, communication, magic or religion, among others (Huber, 1995b; Rodríguez, 2004, 2005). Fires are usually started in the savannas but they can penetrate the montane and gallery forests thus resulting in the net expansion of savanna areas (Fölster, 1986, Fölster and Dezzeo, 1994, 2001; Kingsbury, 2001; Dezzeo and Chacón, 2005; Dezzeo et al., 2004a, b), a phenomenon that is characteristic of the current GS landscape (Fig. 2).

Palaeoecology can shed some light in this controversy. First of all, the hypothesis of a recent, general GS deforestation is not supported by the available evidence, as treeless savannas have dominated the GS landscape since the beginning of the Holocene (Fig. 3). Some local forest clearing events have been documented during the last millennia, affecting gallery forests of the northern sector, but this occurred within a general savanna landscape (Leal et al., in press). In the southern sector, the most recent landscape disturbance was the introduction and spreading of the morichales some 2000 years ago, which also occurred within a savannadominated vegetation. Anthropogenic fires played a role in these transformations, but no general GS deforestation has been documented by past records. The only savannization event recorded began in the YD and ended in the early Holocene, with fire as an important driver. However, this event has been recorded only in the southern sector and we should wait for further studies from the northern part to realize whether this savannization was a general GS pattern. A role for humans has also been suggested in this case. The cultural identity of humans involved in these major landscape disturbances is still a matter of speculation. It has been suggested that YD fires could be linked to the first South American colonizers, whereas 
the Late Holocene fires could be related to the present-day GS Pemones. These hypotheses should be tested with archaeological studies (Rull et al., 2015). Past GS records also suggest that climate has been a relevant driver of ecological change, as fire exacerbation events coincide frequently with drier climatic phases (Rull et al., 2013). Climate has been recognized as a fundamental factor in fire propagation, especially in savannas where dry conditions promote extensive burning (Beerling and Osborne, 2006). However, the first and most necessary event to initiate any fire is the occurrence of a lighting event, either natural or anthropogenic. In the GS, most fires recorded in palaeoecological studies have been considered to be of anthropogenic origin but modulated by climate (Rull et al., 2013; Leal et al., in press).

The empirical dismissal of a recent and general GS deforestation event does not mean that palaeoecological records support the view of the defenders of present-day indigenous practices. This option is based mainly on cultural considerations and will not be discussed here, but the idea that the current indigenous use of fire could contribute to preventing potentially catastrophic wildfires may be subjected to empirical scrutiny using ecological and palaeoecological evidence. Some present-day ecological studies suggest that in the forestsavanna ecotones local environmental conditions favour the accumulation of biomass, which could favour the occurrence of potentially catastrophic wildfires (Sletto, 2008; Bilbao et al., 2010; Sletto and Rodríguez, 2013; Leal et al., in press). The occurrence of wildfires, however, has not been documented in past or present-day records of the GS, where it is widely recognized that humans are, and have been, the main burning agents. Natural fires are comparatively negligible (Huber, 1995b). Therefore, a role for wildfires in the shaping of the GS landscape is still a speculative subject without empirical support. According to the available ecological and palaeoecological evidence, fire prevention, if necessary, should place the focus on human fires, which have been the main factor responsible for the expansion of savanna and 
morichal to the detriment of montane and gallery forests, especially during the Late Holocene (Rull et al., 2013; Leal et al., in press). Another relevant observation is that today's fire practices tend to implicitly prioritize the savannas and morichales, which are currently expanding at the expense of rainforests (Rull and Montoya, 2014). This leads into another debate about specific conservation targets, which is a topic developed in the next section.

\section{Spatiotemporal heterogeneity and restoration targets}

Another important outcome of the latest palaeoecological studies is the realization that the GS landscape is far from being homogeneous and that its heterogeneity has been shaped by the action of natural (climatic) and anthropogenic (fires) drivers over the last millennia. Until recently, this view was restricted to the southern sector (Rull et al., 2013), but Leal et al. (in press) extend the picture to the entire GS. This point has important consequences for conservation planning. Sometimes, the term "conservation" is used in an overly-general sense, which may impede communication with colleagues and stakeholders, thus hampering the adoption of preventive actions. A more practical approach is to define specific conservation targets. Palaeoecological information can be crucial for the definition of these targets. An example is the study of Foster and Motzkin (2003) developed in the grasslands, heathlands and shrublands of the coastal region of New England (USA), where conservation proposals were based on the assumption that the original landscapes were non-forested and maintained by natural disturbance and indigenous land use. Further palaeoecological studies showed that former landscapes were in fact forested and that open vegetation was the consequence of forest clearance and further land use by European colonizers. After these findings, conservation perspectives changed and were oriented towards "a combination of approaches that replicate the effects of historical land use" (Foster and Motzkin, 2003). In the case of the GS, we can ask what we should preserve: the forests, the savanna, the morichales, or all of 
these things? Additionally, considering that the present GS landscape is mostly cultural, we could also ask whether it should be preserved as it is or whether it should be restored to a former, more natural state. In this case, the palaeoecological record has the key information required. Combining the palaeoecological information currently available for the northern and southern GS (Rull et al., 2013; Leal et al., in press), the landscape has experienced at least three main states during the last 13,000 years: i) woodlands of heterogeneous composition with patches of savanna $(13,000$ to 10,000 cal BP); ii) treeless savannas with gallery forests and without morichales (10,000 to $2000 \mathrm{cal} \mathrm{BP})$; and iii) treeless savannas with gallery forests and morichales in the south (2000 cal BP to present). Considering these states as potential restoration targets requires some discussion.

The first state is unsustainable as Late glacial climates were cooler and drier than they are today in the GS; therefore, former YD woodlands would not be in equilibrium with the presentday climate. The second state would require the removal of present-day morichales, which could be viewed as a socio-ecological aggression because these palm swamps are among the more emblematic elements of the GS landscape and are intensively used by local people, not only in the GS but also throughout the whole Neotropics (Rull and Montoya, 2014). The third option, to maintain the GS landscape as it is and without any restoration actions in spite of its well-known anthropogenic character, would be the least expensive and most socially accepted. However, given the spatiotemporal heterogeneity recorded in past and present ecological surveys, one single conservation strategy for the whole region seems inadequate. It might be useful to subdivide the GS into a number of landscape units, more or less homogeneous in both past and present vegetation patterns, and consider the combination of conservation and eventual restoration actions at the local scale. For example, in the localities studied by Leal et al. (in press), the restoration of the former gallery forests would be considered. An additional advantage of such a microsite conservation framework is that it would be more feasible and 
would facilitate eventual agreements among the different actors involved, thus contributing to the preservation of local cultural traits. Some initiatives of this type, with the active participation of indigenous communities, are already ongoing (Rosales et al., 2013) but so far they are isolated ventures. It would be desirable to develop a more general management plan for the whole GS and to include these actions in a broader context for regional coherence.

\section{Final remarks}

Palaeoecological records provide useful information for conservation and restoration actions but do not solve the debate between the critics and the defenders of the use of fire by indigenous GS people. The main reason is that this debate is unrealistic because it is based only on two opposing and inflexible positions and does not consider the whole range of possibilities for a suitable management of the GS. The dispute is rather simplistic, i.e., fire suppression vs. the continuity of indigenous fire practices, and guided by a priori ideological and socio-economic positions. One of the main lessons of palaeoecology is that the GS landscape has not been immutable through time but, on the contrary, has experienced multiple ecological states under the synergistic action of natural and anthropogenic drivers. This temporal heterogeneity overlaps with a significant environmental diversity in space to produce a complex ecological scenario that should be taken into account in any realistic conservation planning. In addition, as Leal et al. (in press) noted, not only the biological but also the cultural components of diversity should be preserved. Therefore, it seems the wiser option to preserve the ecological and cultural heritage of the GS, an emblematic neotropical region, by putting aside intransigent positions and agreeing on a common conservation agenda with the participation of all the stakeholders. It would also be helpful to place the debate in a wider context considering the whole range of the neotropical savannas, in order to share information, ideas and experiences. Palaeoecological studies on neotropical savannas are 
widespread and representative of diverse biogeographical regions (Flantua et al., 2015). These studies have provided relevant insights on the ecological dynamics of savannas and savannaforest ecotones (e.g. Berrío et al., 2012; Mayle \& Whitney, 2010). This information could be used to inform conservation planning at a continental scale.

\section{Acknowledgements}

This research was funded by the Ministry of Education and Science (grant CGL200600974/BOS), the Ministry of Science and Innovation (grant CGL2009-07069/BOS) and the Banco de Bilbao Vizcaya Argentaria Foundation (grants BIOCON 2004-90/05 and BIOCON 2008031). 


\section{References}

Beerling DJ and Osborne CP (2006) The origin of the savannah biome. Global Change Biology 12: 2023-2031.

Berrio JC, Wouters H, Hooghiemstra H, Carr AS and Boom A (2012) Using palaeoecological data to define main vegetation dynamics along the savannah-forest ecotone in Colombia: implications for accurate assessment of human impacts. In: Myster RW (ed) Ecotones between forest and grassland. New York: Springer, pp. 209-225.

Bilbao BA, Leal AV and Méndez CL (2010) Indigenous use of fire and forest loss in Canaima National Park, Venezuela. Assessment of and tools for alternative strategies of fire management in Pemón indigenous lands. Human Ecology 38, 663-673.

Castro L and Gorzula S (1986) The interrelations of the Caroní river basin ecosystems and hydroelectric power projects. Interciencia 11: 272-277.

Da Silva JMC and Bates JM (2002) Biogeographic patterns and conservation in the South American cerrado: a tropical savanna hotspot. Bioscience 52: 225-234.

Dezzeo N and Chacón N (2005) Carbon and nutrients loss in aboveground biomass along a fire induced forest-savanna gradient in the Gran Sabana, Southern Venezuela. Forest Ecology and Management 209, 343-352.

Dezzeo N, Chacón N, Sanoja E and Picón G (2004a) Changes in soil properties and vegetation characteristics along a forest-savanna gradient in southern Venezuela. Forest Ecology and Management 200, 183-193.

Dezzeo N, Fölster H and Hernández L (2004b) El fuego en la Gran Sabana. Interciencia 29, 409410.

Fache E and Moizo B (2015) Do burning practices contribute to caring for country? Contemporary uses of fire for conservation purposes in indigenous Australia. Journal of Ethnobiology 35: 163-182. 
Flantua SGA, Hooghiemstra H, Grimm EC, Behling H, Bush MB, González-Arango C, Gosling W, Ledru MP, Lozano-García S, Maldonado A, Prieto A, Rull V and Van Boxel JH (2015) Updated site compilation of the Latin American Pollen Database. Review of Palaeobotany and Palynology, doi 10.1016/j.revpalbo.2015.09.008

Foster DR and Motzkin G (2003) Interpreting and conservin the openland habitats of coastal New England: insights from landscape history. Forest Ecology and Management 185, $127-150$

Fölster H (1986) Forest-savanna dynamics and desertification processes in the Gran Sabana. Interciencia 11, 311-316.

Fölster H and Dezzeo N (1994) La degradación de la vegetación. Scientia Guayanae 4, 145-186. Fölster H, Dezzeo N and Priess JA (2001) Soil-vegetation relationship in basedeficient premontane moist forest-savanna mosaics of the Venezuelan Guayana. Geoderma 104, 95-113.

Hernández L, Dezzeo N, Sanoja E, Salazar L and Castellanos H (2012) Changes in structure and composition of evergreen forests on an altitudinal gradient in the Venezuelan Guayana Shield. International Journal of Tropical Biology and Conservation 60: 11-33.

Huber O (1995a) Vegetation. In: Steyermark JA, Berry PE and Holst BK (eds) Flora of the Venezuelan Guayana. Volume 1. Introduction. St. Louis: Missouri Botanical Garden Press, pp. 97-160.

Huber O (1995b) Conservation of the Venezuelan Guayana. In: Steyermark JA, Berry PE and Holst BK (eds) Flora of the Venezuelan Guayana. Volume 1. Introduction. St. Louis: Missouri Botanical Garden Press, pp. 193-218.

Huber O and Febres G (2000) Guía ecológica de la Gran Sabana. Caracas: Nature Conservancy. Kingsbury ND (2001) Impacts of land use and cultural change in a fragile environment: indigenous acculturation and deforestation in Kavanayén, Gran Sabana, Venezuela. Interciencia 26: 327-336. 
Klink CA and Machado RB (2005) Conservation of the Brazilian cerrado. Conservation Biology

19: 707-713.

Leal A, Bilbao B, Berrio JC, Behling H, Motnoya JV and Méndez C (in press) Late Holocene gallery-forest retrogression in the Venezuelan Guayana: new data and implications for the conservation of a cultural landscape. The Holocene

Mayle FE and Whitney BS (2012) Long-term prespectives on tropical forest-savannah dynamics in lowland Bolivia from the Last Ice Age until present. In: Myster RW (ed) Ecotones between forest and grassland. New Yor: Springer, pp. 189-207.

Middleton BA (2013) Rediscovering traditional vegetation management in preserves. Trading experiences between cultures and continents. Conservation Biology 158: 271-279.

Montoya E and Rull V (2011) Gran Sabana fires (SE Venezuela): a palaeoecological perspective. Quaternary Science Reviews 30: 3430-3444.

Rodríguez I (2004) Conocimiento indígena vs científico: El conflicto por el uso del fuego en el Parque Nacional Canaima, Venezuela. Interciencia 29, 121-129.

Rodríguez I (2007) Pemon Perspectives of Fire Management in Canaima National Park, Southeastern Venezuela. Human Ecology 35, 331-343.

Rosales J, Deza ME, Delgado L, Chani H, Machuca R, Alvarado M, Parra M, Reyes F, Pérez F, Aparicio E, Rodríguez G, Valeri C, Blanca R, Hernández L, Sánchez B, Salazar L, Ortega A, Pérez J, Sanoja E, Rodríguez G and Bilbao B (2013). Restauración de bosques de galería en paisajes con mosaico sabana-bosque y potencialidad de participación de los PemónArekuna. In: Siminian LL (ed), Biodiversidade, conservaçao dos recursos naturais e cultura. Donaeo Eds, pp. 128-151.

Rull V (1992) Successional patterns of the Gran Sabana (southeastern Venezuela) vegetation during the last 5000 years, and its responses to climatic fluctuations and fire. Journal of Biogeography 19, 329-338. 
Rull V, Montoya E, Nogué S, Vegas-Vilarrúbia, T. and safont E (2013) Ecological palaeoecology in the neotropical Gran Sabana region: long-term records of vegetation dynamics as a basis for ecological hypothesis testing. Perspectives in Plant Ecology, Evolution and Systematics 15: 338-359.

Rull V and Montoya E (2014) Mauritia flexuosa palm swamps: natural or human-made? A palynological study of the Gran Sabana region (northern South America) within a neotropical context. Quaternary Science Reviews 99: 17-33.

Rull V, Montoya E, Vegas-Vilarrúbia T and Ballesteros T (2015) New insights on palaeofires and savannistion in northern South America. Quaternary Science Reviews 122: 158-165.

Schmidt PM and Peterson MJ (2009) Biodiversity conservation and indigenous land management in the era of self-determination. Conservation Biology 23: 1458-1466.

Sletto B (2008) The knowledge that counts: institutional identities, policy science, and the conflict over fire management in the Gran Sabana, Venezuela. World Development 36, 1938-1955.

Sletto B and Rodríguez I (2013) Burning, fire prevention and landscape productions among the Pemon, Gran Sabana, Venezuela: Toward an intercultural approach to wildland fire management in Neotropical Savannas. Journal of Environmental Management 115, 155166.

Vegas-Vilarrúbia T, Rull V, Montoya E and Safont E (2011) Quaternary palaeoecology and nature conservation: a general review and some examples from the Neotropics. Quaternary Science Reviews 30: 2361-2388.

Welch JR (2014) Xavante Ritual Hunting: anthropogenic fire, reciprocity, and collective landscape management in the Brazilian cerrado. Human Ecology 42: 47-59. 


\section{Figure captions}

Figure 1. A) Leaf area index map of northern South America showing the distribution of forests (green area) and the position of the Gran Sabana region (orange box), NW of the Roraima Savannas (RS). Base map from NASA Earth Observatory (http://earthobservatory.nasa.gov). B) Map of the Gran Sabana showing the location of palaeoecological records available (red dots). Northern sector: Ariwe Fernland (AF) and Quebrada Kowana (QK) (Leal et al., in press). Southern sector: Lake Chonita (LC), Lake Encantada (LE), Lake Fidencio (LF), Mapaurí peat bog (MP), Paují peat bog (PP) and Urué peat bog (Rull et al., 2013, 2015). Modified from Rull and Montoya (2014).

Figure 2. Examples of Gran Sabana fires. A) Active savanna burning near Sta. Elena. B) Savanna expansion at the expense of gallery forest near Kavanayén. C) Montane forest recently burnt being colonized by savannas (Chimantá massif, near Yunek). See Fig. 1 for the mentioned localities. Photos: V. Rull.

Figure 3. Schematic summary of the main results of palaeoecological studies developed thus far in the southern sector of the Gran Sabana at millennial scale. This figure is a composition of nine sites, i.e. those depicted in Figure 2 and others (Santa Teresa and Divina Pastora) from Rull (1992), all of them with mid-late Holocene records and almost all containing also preHolocene and early Holocene sequences. Based on Rull et al. $(2013,2015)$ and literature therein. 

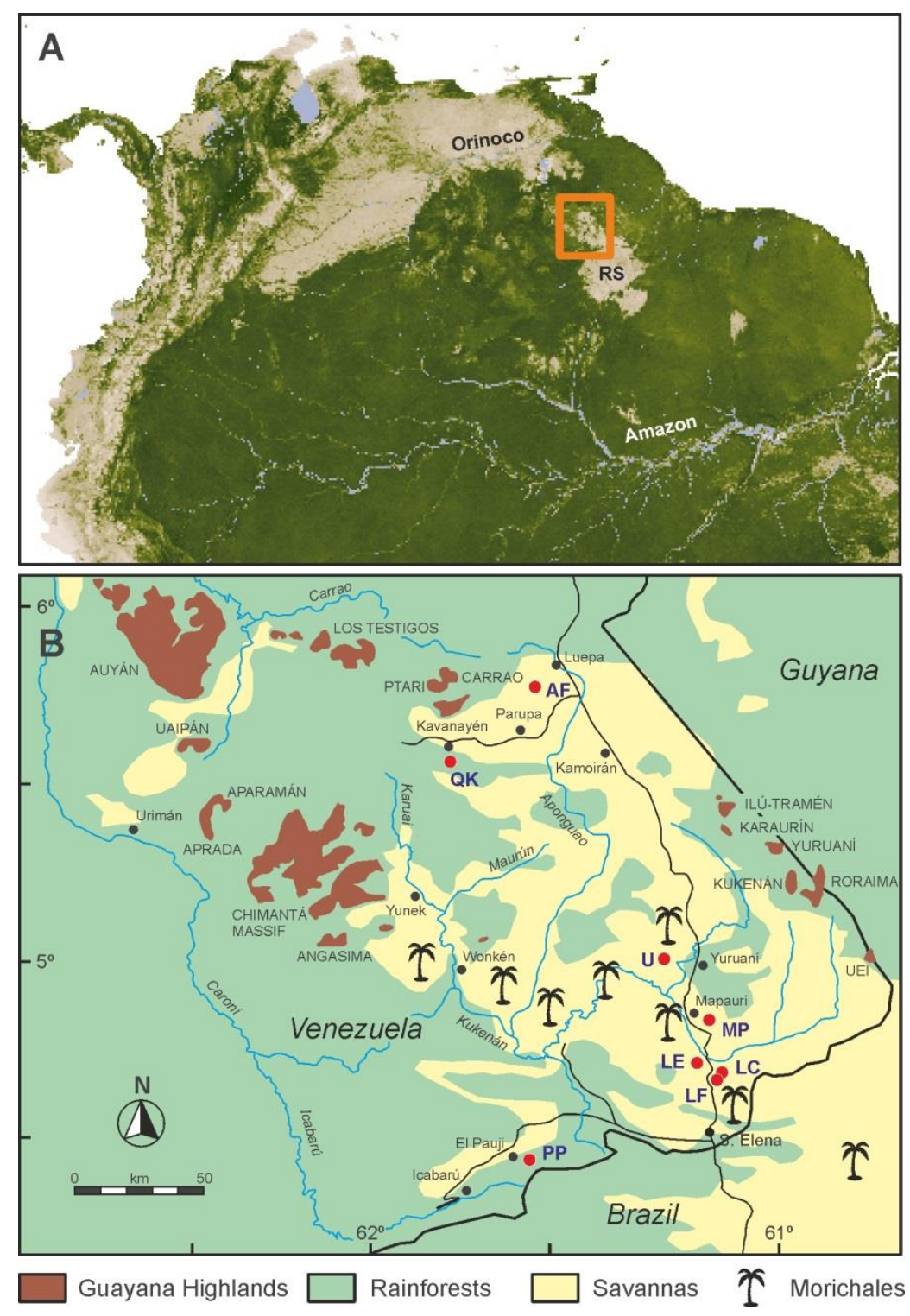

Figure 1 

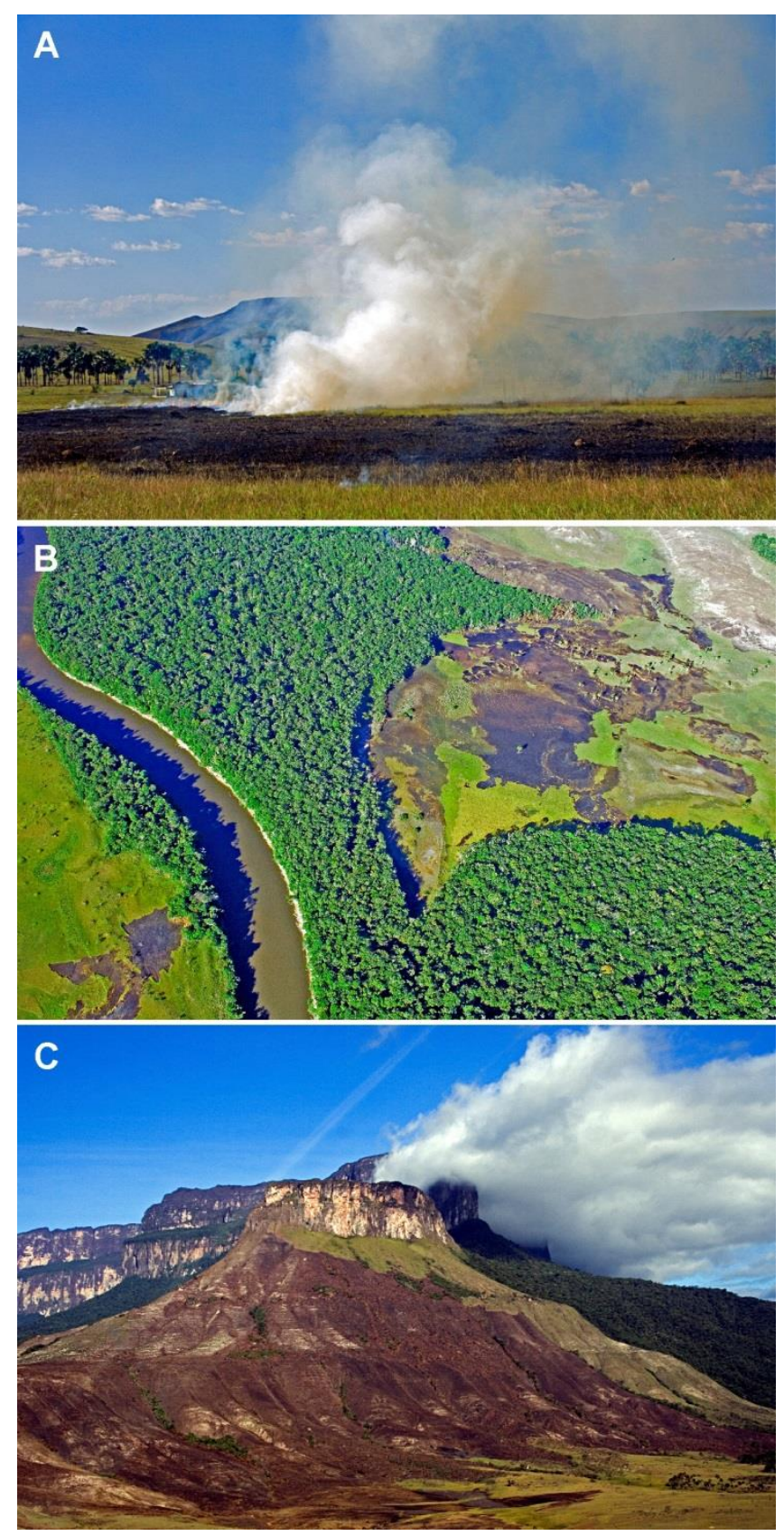

Figure 2 


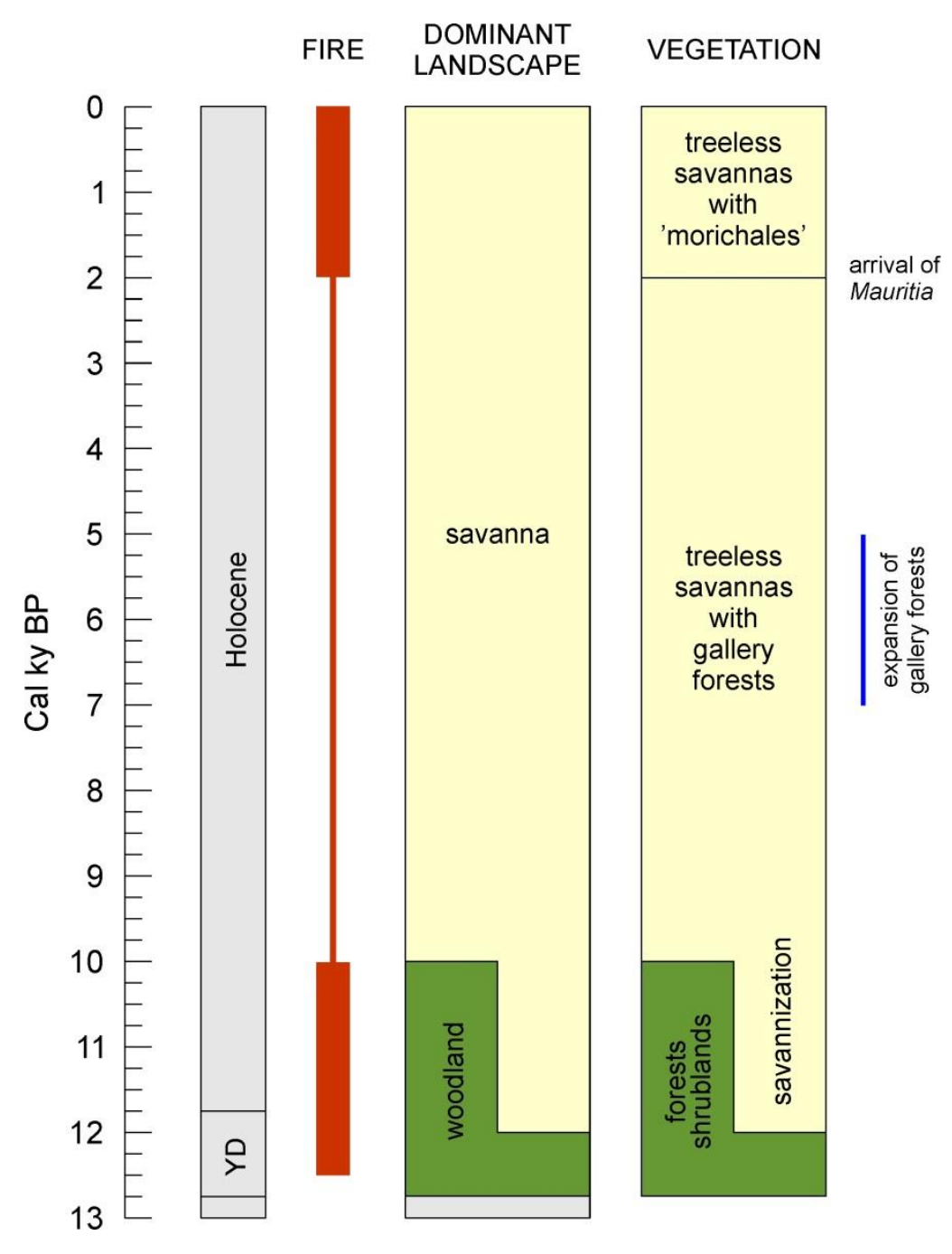

Figure 3 